\title{
QUEEN'S
UNIVERSITY
BELFAST
}

\section{Ambivalences of Cosmopolitanisms, Elites and Far-Right Populisms in Twenty-First Century Europe}

Vieten, U. M. (2018). Ambivalences of Cosmopolitanisms, Elites and Far-Right Populisms in Twenty-First Century Europe. In J. Mackert, B. Turner, \& G. Fitzi (Eds.), Populism and the Crisis of Democracy (Vol. 2, pp. 101-118). Routledge.

Published in:

Populism and the Crisis of Democracy

Document Version:

Peer reviewed version

Queen's University Belfast - Research Portal:

Link to publication record in Queen's University Belfast Research Portal

Publisher rights

(C) 2018 Routledge.

This work is made available online in accordance with the publisher's policies. Please refer to any applicable terms of use of the publisher.

\section{General rights}

Copyright for the publications made accessible via the Queen's University Belfast Research Portal is retained by the author(s) and / or other copyright owners and it is a condition of accessing these publications that users recognise and abide by the legal requirements associated with these rights.

Take down policy

The Research Portal is Queen's institutional repository that provides access to Queen's research output. Every effort has been made to ensure that content in the Research Portal does not infringe any person's rights, or applicable UK laws. If you discover content in the Research Portal that you believe breaches copyright or violates any law, please contact openaccess@qub.ac.uk. 
Ambivalences of cosmopolitanisms, elites and far-right populisms in twenty-first century Europe

\author{
Ulrike M Vieten
}

Modernization theory ... lies behind the widely shared view that the United States and the Soviet Union are evolving toward one another and eventually will develop very similar social systems. This is a view that suits men and women of different political persuasions: it can provide the basis for arguments about Soviet liberalization or incipient American totalitarianism. (Michael Walzer, 1980: 195)

\title{
Introduction
}

The rise of far-right populism and a return to nationalistic tunes in Europe and beyond evolved rapidly since 2008, and with a further push in 2016. This is not by chance as 2008 was the year of international economic crisis, and summer 2015 has become identified with what media and politics call, migration crisis. While drawing on Hay's (1996) notion of 'crisis' Sylvia Walby (2015: 17) stresses that the meaning of crisis is 'subjectively perceived and brought into existence through narrative and discourse'. Further she underlines the relevance of temporality as crisis is identified with rupture, with a state of exemption and, accordingly, contrasts with other more 'normal' times. (ibid.). What has become normal or normalised (Vieten, 2014), however, has not been normal only a few years ago. Attention shifted from discourses of cosmopolitanism to neo-natonalism and here, far-right populism in Europe.

In 2014, Ernst Hillebrand edited a short booklet on Right wing populism in Europe: How do we respond?, published with the German Friedrich Ebert Stiftung. All authors asked for an engagement with the roots of recent far-right populism endemic to the current political legitimacy crisis and social-economic transformations, in and across different European societies pushed by globalisation and Europeanisation. Anthony Painter (2014:4), for example, argues,

'Evidence-based politics is lauded. Facts become the determinants of political debate rather than people. So people are told that welfare dependency isn't an issue, they should celebrate immigration, climate change is fact, the EU is good and efficient, cultural 
tensions are a figment of their imagination. The problem with this approach is that perception is reality in politics ${ }^{1}$ - whatever the truth or otherwise of these statements. So if you are silent or if your starting point is that people are wrong then good luck. And that is exactly what the populists want you to do.'

Perception plays a central role in contemporary media-democracy: Margit Feischmidt and Peter Hervik (2015) argue that media has triggered the scandalising and criminalisation of minorities and migrants; first, far-right media criminalized minorities, but then many actors in mainstream media and politics adopted this as strategy, too (ibid.).

Ruth Wodak's research trajectory of years demonstrates how 'a politics of fear' (Wodak, 2015) has developed discursively in politics and media, and how racism and discourse are interwoven and constructed (Wodak, 2013). Though the role of media has been problematized in forging ideological views (see also Feischmidt and Hervik, 2015) it is only recently that populist anti-elite anger dominates political debates, media and public spaces. Foremost, anti-elite sentiments push the success of far-right parties in Europe and internationally.

It seems with the 2017 slogan of 'post-truth' (Ball, 2017) we need a deeper understanding how perception of 'we' and 'them' is constructed, and 'who is who' (Wodak, 2017) in this discursive battle. Here, the focus will be on the notion of elite and the way it is constructed in discourses of cosmopolitanism and of far-right populism. ${ }^{2}$

In the following, I will talk first about situated discourses of cosmopolitanisms with respect to two discursive ideological positions (Weltbürger-Kosmopolit), e.g. historical antiSemitic and intrinsic racialising boundary drawing within discourses of cosmopolitanism, and further, reflect on the critique of cosmopolitanism as an elite project. Then second, the notion of 'elite' in contemporary far-right populism will be discussed while focusing on the British context, and also on the project of EU/European mobility as linked to notions of cosmopolitan 'elites'. Here, EU citizen freedom rights as trans-border mobility is regarded as an indicator of legal, economic and political transformation, however, as it becomes clear only activated by a relative minority of EU citizens. The chapter will conclude by arguing that we have to look more in-depth at particular elite regimes established in different countries when talking about populist anti-elite sentiments, also trying to understand to which degree nationalist counter-elites establish themselves as antitransnational and anti-cosmopolitan, but 'communitarian' elites. 
Situated cosmopolitanisms and the notion of the Other

Only ten years ago academic literature and debate was in full swing with cosmopolitanism, conviviality and multiculturalism. Today this euphoric, and as it will be seconded here, largely (middle) classed 'perception' of what the state of twenty-first century European societies might look like, turned its pages: by now it is foregrounding EU scepticism, xenophobia and social anxieties.

The 'London School of Economics' academics like David Held and - associated - Ulrich Beck, as Craig Calhoun (2017: 63) stresses, epitomised cosmopolitan ambition and discourse of the city: urban elites, including most mainstream politicians (but also academics, UMV) regarding themselves as cosmopolitan and, for example, the English 'countrymen as backward' (ibid.).

Nigel Farage, the ex-leader of the UK Independent Party (UKIP) embodies the cliché of this kind of beer drinking white English countryman; Farage, however, being also the middle class English man, who is elected member of the European parliament since 1999, confirmed in office in the last EU parliament election in 2014, and also married to a German citizen. This paradox of cherishing a 'backward' version of Englishness and an 'island view' while trying to keep the freedom rights of European citizenship ${ }^{3}$ might give some clues of the apparently contradictory though related discourses of new cosmopolitanism and contemporary far-right populism.

I will go back here to my previous work on situated cosmopolitanisms (Vieten, 2007; 2011; 2012) analysing discourses on cosmopolitanism before and after 9/11 2001 in publications by what I called 'mainstream' academics - among them Jürgen Habermas, Ulrich Beck, and David Held - and contrasting these texts with publications by minority or cosmopolitanism-critical scholars, such as Chantal Mouffe, Homi K. Bhabha, and Hanna Behrend. While, inspired by Emanuel Levinas (1991), theoretically differentiating 'difference as plurality' and 'otherness as beyond diversity', mainstream academics advocating new cosmopolitanism were interrogated to which degree they favoured an allinclusive cosmopolitanism or rather an ideological project of European 'cosmopolitan' identity. The latter has to be seen as particularly problematic as it addresses Islam and orthodox Muslims as positioned 'outside' the 'civilisational' cosmopolitan realm.

While analysing German and English archive material of the late nineteenth and early twentieth century the study showed that in a historical Germanic discourse cosmopolitanism comes with the racist luggage of a conceptual distinction of Weltbürger (citizen of the world) and Kosmopoliten. The latter targeted Jews as 'outsiders' and 
addressed Jews as people without roots (Vaterlandlose Gesellen). The two-tiered position of a gentile Weltbürger and the anti-Semitic label Kosmopolit illustrate an intrinsic construction of racialised boundaries. This anti-Semitic discourse was historically connected to German nationalism and an ideological völkisch -ethnic project of state building. The debates on new cosmopolitanism apparently ignored, or did not grasp the meaning of this two tiered discursive social (and legal-illegalising, later on) categories.

Ulrich Beck, Jürgen Habermas and David Held were advocating in their publications the multi-layered polity of the European Union and a new version of European cosmopolitan identity: in Calhoun (2017) terms: the cosmopolitan 'LSE' project.

Following my in-depth text analysis of publications before and after 9/112001 a binary seemed to have been built into new European cosmopolitanism: the ideological project of pushing cosmopolitan European identity was associated with the polity of the European Union while at the same time post 9/11 non-secular Muslims as minority religious and ethnic communities, e.g. Orthodox Islam, were targeted and approached as outside the European civilizational realm.

However, feminist interventions from e.g. Hanna Behrend and Chantal Mouffe as well as post-colonial interventions, e.g. Homi K. Bhaba pinpointed that mainstream cosmopolitanism, indeed, showed a lack of engagement with intersecting angles of gender, race and class (e.g. participation of women and white working class people). But equally some of these critical writings also had to face up to a dilemma: a mundane focus on visible minorities and migrant communities (e.g. stripped of socially dividing categories) as agents of transnational and diasporic cosmopolitan activity also fell short of taking into account differentiated social positions.

While mainstream advocates of new cosmopolitanism were not taking on board a racialised boundary (or to put it differently: the inherent group boundary drawing as racializing otherness) with respect to the discourse of historical Germanic cosmopolitanism the long term impact of this ambivalent discourse on constructing racialised group boundaries (nationalism and cosmopolitanism) when denying this 'dark' side left speculations open when it might come up again, and how racism would look like encompassing the ideological project of European cosmopolitanism. The idea of European cosmopolitanism fitted an orientation of middle class economic social mobility, rather rejecting nationalism and seeking to encourage individual social upward mobility linked to the European Union integration goal. In what ways was new cosmopolitanism reserved to European and international mobile elites? 
New cosmopolitanism and 'the elite'

Though cosmopolitanism has been critically discussed and analysed across different disciplinary fields, by scholars such as Cheah and Robbins (1998), Cheah (2006), or by feminist academics such as Mica Nava $(2002 ; 2006)$ and Eleonore Kofman (2005) and post-colonial voices (Mignolo, 2000; 2002; Nwanko, 2005; De Souza Santos, 2010) the contrast between 'travelling elites' and 'immobile locals,' as a socially explosive class parameter was mentioned, but not tackled in its political consequences. Having said that, cultural theorists such as James Clifford (1992: 108) stressed the need to avoid 'the excessive localism of particularistic cultural relativism as well as the overly global vision of capitalist or technocratic monoculture'. Clifford highlighted that there has to be a mediation of local and 'global' encounters. Not unlike Pnina Werbner (1999), who followed the traces and routes of minority working class cosmopolitans, Clifford also put emphasis on the fact that not only bourgeois and privileged people were moving, travelling and becoming cosmopolitans, but less privileged groups such as female servants, domestic workers and migrants (e.g. ethnic diasporas) were part of this emerging cosmopolitan realm (ibid.). Reflecting on 'vernacular cosmopolitanism' (Bhabha, 1996) Werbner argues: 'If we take vernacular cosmopolitanism to refer to a multi-centred world, beyond the West, in the sense proposed by Arjun Appadurai, it is perhaps among the elites of such cosmopolitan cities that distinctive vernacular cosmopolitanisms are created' (Werbner, 2006: 498).

Werbner's conclusion, however, encapsulates the pitfalls of this kind of metropolitan cosmopolitanism discourse: cosmopolitanism remained largely associated with cities and urban elites, and in this reading did not appeal to vernacular experiences that might be far from the multi-cultural centre and contained in provinces. Having said that Ulf Hannerz (1990: 249) detailed the differences, but also dependencies between cosmopolitans and locals though underestimated that the 'national/nation-state' layer discursively and regulatory is interfering in the relationship between the local and the global (e.g. or the European level, for that purpose). Some of the critiques of new and liberal cosmopolitanism, for example Chantal Mouffe $(2004 ; 2005 ; 2008)$, clearly pinpointed the classed, e.g. middle classed, character of new cosmopolitanism, and linked it to global capitalist interests. Foremost, the meaning of power was contested in this regard ${ }^{4}$ and as far as Mouffe's interventions are concerned, insisted on the importance of the political territorial container 'nation state'. 
In my interpretation Mouffe was prolific in denouncing liberal cosmopolitanism as an elite project, but she takes stock from the German National Socialist lawyer Carl Schmitt while taking up his terminology of 'a pluriversum'. According to Schmitt (1950) 'the world is no political unit but a political pluriversum' (cited in Hofman, 2003: 7). ${ }^{5}$ Schmitt fundamentally rejected liberal democracy and advocated a polarised view of 'the political' as the battle of 'friends' against 'enemies'. ${ }^{6}$ According to Feischmidt and Hervik, Samuel Huntington was inspired by Schmitt's statements, cited by these authors as 'We don't know who we are, if we don't know our enemies' (Feischmidt and Hervik, 2017: 9).

The world of binaries also is inscribed in the discursive contrast of normative discourses of cosmopolitanism and nationalism. Craig Calhoun (2002; 2007), certainly, represents best those voices, who warned of a naïve understanding of both concepts sidelining the 'Janus face' of cosmopolitanism, and thus ignoring that both, nationalism and cosmopolitanism hold the potential to create good and bad things. This, by the way, also was the position of the late Hanna Behrend, a Jewish and East German socialist voice in Germany, who was marginalized in the German discourse of the 2000s, which was reluctant to accept any positive notion of German national identity.

According to Renisa Mawani (2012) who looked at cosmopolitanism as an ethical and political vision of living with difference, 'racisms are immanent and organizing logic manifest in the production of racial heterogeneities and differentiations upon which cosmopolitical visions depend and also generative of the cosmopolitan outlook these encounters are thought to require' (Mawani, 2012: 1083). Agreeing with this, we have to be cautious about the cosmopolitan 'openness' towards the Other, and take into account that new cosmopolitanism operates with culturalist assumptions, particularly targeting non-secular and minority religious groups.

To summarise my considerations thus far: after the praise of (new) cosmopolitanism between 1990 and 2015 we are confronted with the agony of global neo-liberalism and the limits of a cultural European cosmopolitan identity project. There is an urgent need to stand up to wide spreading (far-right) populisms reminding us of the dark side of the cosmopolitan dilemma.

Mainstream academic and political debates a decade ago failed a more utopian cosmopolitan vision of global social justice rather pursuing a highly middle classed version of European cosmopolitanism. Whereas for a decade we witnessed a process of a normalisation of difference (Nava, 2007), the Other as the 'irregular' (Broeders, 2007: 71) migrating or 'risky' cosmopolitan was left outside a mundane notion of European 
cosmopolitanism. The Other was the 'migrant' or the refugee (Vieten, 2007) and this construction of exclusion within a discourse of liberal cosmopolitanism comes to the fore now with an extreme face of far-right populist racism, e.g. Anti-Muslim racism. In effect, the role of elites in pushing cosmopolitan lifestyle and culture was criticised by for example scholars such as Chantal Mouffe yet a decade ago, but it was not further interrogated how nation state based electorates of'the people' frame and understand'their' elites.

Next, I will look at the UK context surrounding the Brexit decision of June 2016, and ask in what ways far right messages entered centre stage of mainstream politics, and to which degree layers of a de-territorialized understanding of cosmopolitanism and what I call 'populist territorialism' are propagated in contemporary centre right conservative politics. Thus, I will turn to the notion of elite in the discourse of centre right and far-right populism: What does anti-elite mean in the context of contemporary far-right populism? Calhoun (2017: 63) argues more recently that 'populism flourishes when people feel betrayed by elites.'

In what ways do we have to distinguish between national nation-state elites though and (transnational) elites of new cosmopolitanism? Is there a cleavage between cosmopolitanism and populism?

\section{The normalisation of far-right perspectives and anti-cosmopolitanism in Britain: citizens, elites and 'the people'}

It is debatable, indeed, to which degree Britain's history of a colonial and commercial cosmopolitanism perpetuated a very much classed society, wrapped up in hegemonic whiteness and not engaging with coloured social class (on top and intersecting with gender and ethnicity, for example). Not only Tony Blair supporter Anthony Giddens, but those, who have been politically and economically in charge backed a mainstream UK policy that did not challenge the cultural and economic centralism of London. In 2016, the mainstream political tunes have changed drastically though.

The current British Prime Minister Theresa May denounced cosmopolitans as those without abode while alluding to 'rootless' cosmopolitan citizens of the world: '[I]f you believe you're a citizen of the world,' May said on October 5, 2016 at the Conservative party's conference, 'you're a citizen of nowhere. You don't understand what the very word 'citizenship' means.' 
The short quote cited above has to be contextualized within a larger paragraph where May is defining and explaining her notion of citizenship as embedded in a sense of community, family and traditional, territorially connoted, obligations. As cited here, May announced:

'The spirit of citizenship. That spirit that means you respect the bonds and obligations that make our society work. That means a commitment to the men and women who live around you, who work for you, who buy the goods and services you sell. That spirit that means recognising the social contract that says you train up local young people before you take on cheap labour from overseas....too many people in positions of power behave as though they have more in common with international elites than with the people down the road, the people they employ, the people they pass in the street. But if you believe you're a citizen of the world, you're a citizen of nowhere. You don't understand what the very word 'citizenship' means. So if you're a boss who earns a fortune but doesn't look after your staff...An international company that treats tax laws as an optional extra.' (The Guardian 6 October, 2016) ${ }^{8}$

Two things stand out in this part of May's speech: for one, her anti-cosmopolitan statement echoes anti-Semitic stereotypes that seemed to be off mainstream discourse and debate, previously, and second, she brings discursively together 'citizens of the world' with 'international elites' on the one hand, and by that stressing her and her conservative party as truly taking responsibility for territorially and nation state bounded communal bonds, and the 'real' citizen, on the other.

Implied is that those, who are mobile migrants or only temporary living in a place are not and cannot be citizens; it also alludes to a transnational business and capitalist class, not paying taxes in nation states and thus undermining the redistribution of wealth. ${ }^{9}$ On the background of a policy of austerity supported by different British labour as well as conservative governments while deregulating worker and social rights and by that pushing global liberal market capitalism the 'new start' Theresa May promises is astounding. She is constructing a narrative, which addresses sections of the UK citizen population, who are framed in terms of locally bounded and non-cosmopolitan characteristics. She allies herself and her party to this 'local' experience. Her speech is framed in populist terms and indicates that the boundaries between what the conservative Tory party has to say, and what the far right such as UKIP might (have) push(ed), has become blurred, in only a few years. Camil-Alexandru Pârvu argues: 
'There is no polar opposition, therefore, between the populist promise of a massive simplification of politics through the critique of representative institutions, impatience with the bureaucratic and procedural forms and reification of the nation-state as site of predilection for making decisions, and cosmopolitans' vision of a transnational democracy. Despite all the manifest differences between these two clusters of political visions, they share an underlying notion of rescuing a radical form of collective political agency from the current impasse.' (Pârvu, 2016: 116)

Seconding some of Parvu's scepticism it has to be said that it is highly problematic to construct an opposition between the current face of populist territorialism and the deterritorialized vision of a trans-national cosmopolitan democracy. Both avoid answering uncomfortable questions of political and social transformations as well as democratic complexity. What we face is a crisis of political representation impacting on contemporary forms of populism (Taggart 2000) that challenges notions of territorial representative democracy. In what ways are the characteristics of the so called 'international' elite, the cosmopolitan elite and communitarian claims, the latter made by Theresa May recently more typical of a general and shifted discourse of citizenship (obligations), territorialist or 're'-territorialized understandings of community, and an altered construction of 'the elite'? Next, the discourse on elites in far-right populism will be examined.

\section{Far-right racist populism, individualism and the notion of elite}

Robert S. Jansen (2015), Jose Pedro Zùquete (2015) and Cas Mudde (2015) agree that foremost, populist mood is driven by strong anti-elite anger; and further, that there is a claim to be nativist, and nativism here means, to have an inherited entitlement to the common good of a society. Nira Yuval-Davis (2011) is sceptical of the term 'nativist', and instead suggests 'autochthony' following the writings of Peter Geschiere (2009). Geschiere defines 'autochthonic politics as the global return to the local' (cited in Yuval-Davis and Vieten, 2018 forthcoming), which is related to different forms of racialisation as 'temporalterritorial racialization, of exclusion and inferiorization' (ibid.) of those, who rupture the local order. Wodak (2017) interestingly, raises the issue of a similar power dynamic of claiming local space, and distinguishing between those who are 'established' and those, who are 'newcomers' when referring to Norbert Elias and John L. Scotson (1965) seminal 
work 'The Established and the Outsider'. Elias and Scotson' study analysed the way established families in 'Winston Parva' kept power, and how 'insider' and 'outsider' configurations operate in a local neighbourhood. A new modifying angle to the 'established-outsider' theory is proposed by Hogenstijn, Van Middelkoop, and Terlow (2008). They call it 'scalar strategies in local conflicts' (ibid: 158) and resume '[W]ithin the local situation, we identified a new category of people: the locally indifferent. They are residents, newcomers or locals, whose networks are individualised and not focused on their place of residence. These individuals did not "elect to belong" (Savage et al., 2005) in their local area, but they are still relevant in a local conflict situation as a potential power source. Established and outsiders can try to gain this power source by claiming or mobilising the locally indifferent.'

This study is nearly ten years old, and some of the observations might be dated, but the phenomenon of differently scaled spaces of influence, and the notion of the 'indifferent' local, who might be a cosmopolitan newcomer to the place, is relevant to the question of how cosmopolitans, locals, national and international elites are characterised in the farright populist discourse. Ten years on, the scale and variation of incoming people, who impact on neighbourhoods and challenge collective majority communities as well as identities, have to be interpreted as a signifier of late modern mobility: it is an indicator of the glocal transformation of social-economic structures.

While referring to Seymour Martin Lipset (1960), Jansen (2015: 201) stresses that 'status loss is one of the most important drivers for the emergence of the radical positions within the electorate', and that ' $(\mathrm{t}) \mathrm{he}$ rise of populist far right parties in Europe is linked to the expansion of the European Union' (ibid.: 197). The enlargement of the European Union and as a side effect of it Europeanisation (Olsen, 2002) affects the social fabric in various countries. Collective and individual rights, social welfare as well as market economy have seen ruptures partly in effect of currency dependency (e.g. austerity policy) and cultural transformations. The formation of elites, and further the notions of identity and cultural belonging across Europe are in a process of redefinition; it seems that the national order of social divisions is in turmoil.

Marko Martin wrote in the Swiss newsletter NZZ, in $2015^{10}$, that the US American sociologist Christopher Lasch with his work on Narcissism might give hints to interpret more accurately the contemporary phenomenon of populism. According to Lasch (1979) pathological narcissism stretches into a version of normality, which might be akin to radical political movements. Though Lasch in his writings referred to the rioting and 
roaring 1960s, and in this respect to a left wing radical uproar, it is questionable to what degree an ego-centric entitlement vision dominates the fantasy and plain action of contemporary far-right wing populism. The phenomenon of a social fragmentation of modernity (post-modernity) might be entangled with a narcissistic version of 'native' or 'autochthonic' entitlements. 'Narcissism and sense of entitlement' are late modern aspects of individualism that shape contemporary far-right populism in a way that is different to its twentieth century emanations.

Contemporary populist rage seems to be connected to missed chances (or imagined missed opportunities) of predominantly white, male and ethno-religious majorities. It seems that an old elite (political class) did not deliver chances and the good of society, and that a new formation of nationalist elite takes over. Having said that, Theresa May gives a good example, of someone, who has been part of the previous political class and elite when serving as Home Secretary since 2010 and until 2016; supporting the previous UK Prime Minister David Cameron and his politics. She and the Tory party only recently jumped on the globalisation and cosmopolitan critical ticket.

How does this shift in orientations of what counts as 'the elite' and who is addressed as 'the people' relate to the trans-territorial mobility rights offered to EU citizens, and how come that larger sections of different EU national societies are disenfranchised from the EU integration project?

\section{EU freedom rights, mobility and (transnational) elites: fact or fiction?}

A special EUROBAROMETER study in April $2017^{11}$ - 2 years ahead of the next European elections - examined the attitudes of citizens of the 28 European Union Member states towards the EU. The researchers found a rise in a positive identification with the EU, but also admit that the majority of interviewed Europeans regarded 'inequality between social classes as most significant' (ibid). The data gathered for EUROBAROMETER differentiated sex (men and women) and occupational groups, but did not take into account intersectional identity angles, such as ethnicity, race or religion. ${ }^{12}$ This is relevant as 'class' seems to be recognised by EU related research though a further differentiation of intersecting social positions is sidelined.

Mihaela Nedelcu (2012) argues that contemporary migrants show a specific form of cosmopolitan capacity while linking different localities through and in their transnational lives. However, the situation of visible minority citizens is very much shaped by violent 
ruptures and ideological barriers to 'belong'; thus, their situation might be characterised by a specific vulnerability, but also with the potential to explore altered transnational spaces. Their 'positionality marks the social situatedness of individual subjects within particular sociospatial contexts and relations to others that shape their knowledge, views, subjectivity, identity, imaginary, and conditions of existence' (Leitner and Ehrkamp, 2006: 1616), and 'also involves power relations, in the sense that uneven power is associated with the placement of individuals in social, cultural, and material space, and within nationstates and the global economy' (ibid.). That means that the presence of transnational migrants on the one hand 'endangers' national narratives of belonging and social cohesion and might be an 'easy' target to be discursively contrasted with the 'national community and its citizens'. When it comes to the European Union level, the 'migrant' background of visible (ethno-racial) minorities in different nation states is absorbed into a broader notion of 'migrants'. EU citizens might be categorised as EU migrants, but the crucial difference to any other grouping of migrants would be that the internal trans-border migration creates a new and distinctive stream of individual citizen rights. The effects of distinctive notions of 'migration' and 'mobility' are introduced below, and also explain in what ways these binary positions tie into the above explained discourses of culturalist European cosmopolitanism.

Table 1. (Migration-Mobility nexus and cosmopolitanism)

\section{Table 1 about here}

Ten years ago, EU citizens seemed to be in a relatively safe legal position. However, the ideological change with regards anti-EU sentiments and anti-EU elites, i.e. 'Brussels' (Wodak, 2017) and the legal-political consequences of the UK's decision to leave the EU triggering Art $50^{13}$ Lisbon Treaty means that there is a redefinition of what migration in Europe means.

But in contrast to the recent scandalising of EU migration the statistics show that only a minority of citizens in all 28 EU Member States actually activate these freedom rights based on Art. 45 TFEU $^{14}$. According to EUROSTAT ${ }^{15}$ in March 2017, a total of 4.7 million people immigrated to one of the EU 28 Member States during 2015, while at least 2.8 million emigrants were reported to have left an EU Member State. Among these 4.7 million immigrants during 2015, there were an estimated 2.4 million citizens of non-member 
countries, 1.4 million people with citizenship of a different EU Member State from the one to which they immigrated, around 860,000 people who migrated to an EU Member State of which they had the citizenship. (ibid)

Given that the current population of the EU is about 508 million we can see that crossborder mobility as migration into another EU coutry has not got the esteem the political and legal designers of the EU freedom rights might have had in mind, initially: the Erasmus Mundus program (European Commission) celebrates this year its thirtieth anniversary, and claims more than 3 million students 'spent part time of their studies abroad'. ${ }^{16}$ Apart from Higher Education, the European Union also is investing in unemployed young people, who want to improve their qualifications while doing an internship in another EU country; this is co-funded by the European Social Foundation (Europäischer SozialFond) and as far as Germany is concerned, also backed by the Bundesministerium für Arbeit und Soziales ${ }^{17}$. All these efforts aim at enhancing cross-border mobility that might translate into individual social mobility (upward mobility), but it is also mapping out a common and more integrated trans-national future for inhabitants of the Member States of the European Union. 'Europe's domestic mobility regime is regularly referred to as a model in theoretical accounts of transnational or postnational citizenship' (Thym, 2016: 296; see also Parker, 2012 for details on EU 'cosmopolitics').

Whereas migration across borders might mean subjectively the same for third country nationals and EU citizens the different constitutional scope of the European Union makes all the difference: mobility as cross-border EU internal migration of citizens is at the centre of the 'community' building processes of the European Union. In consequence, we are confronted with new configurations of 'social mobility' as European 'cross border migration' transforms the meaning of migration engendering new rights for individual citizens. It is here where the emergence of transnational elites is competing with national elites. However, as illustrated it is a minority in proportion, who might be referred to as European transnational elite.

As part of the new world order, a multi-layered and sophisticated system of citizenship rights is constructed across the European Union: 'internal market' migration is welcomed, in principal, but the far-right populist turn to parochical positions is claiming back the nation state container. It is questionable though how internationalisation, Europeanisation and the social-economic transformations encompassed by global neo-liberal capitalism could be just reversed by blaming the EU, or worse, withdrawing social mobility rights of citizens. 
The a-versions towards elites: a kind of concluding remarks

Following these considerations I argue that far-right populism has developed into a normalised and everyday phenomenon in numerous countries, because some of the ambivalences and othering dynamics of new European cosmopolitanism were underestimated. The dark side of historical discourses of cosmopolitanism largely were ignored in the post-1990 years despite an early critique of its elitists classed, racist and gendered normative assumptions. The previously marginal extremist views of far right parties, their activists' racist programs have entered the core of societies, step by step: farright populism as the right of the 'native' and self-proclaimed 'autochthon' Christian Europe, for example, takes discourse and action onto the streets 'fighting' extremist fundamentalist Islam and claiming to 'save our women', particularly, if sexual violence against women is exercised by non-white and non-Christian men. ${ }^{18}$ It seems 'communal' national(ist) 'new' elites have taken over governance in some countries, and joining a territorially based electorate in constructing themselves as belonging to 'the people'. In this discourse, minorities, EU migrants and internationals are blamed as Others not being the right kind of citizen and - going back here to old anti-Semitic stereotypes - targeted as cosmopolitan elite.

It has become difficult to draw the line exactly between centre right and far right political parties as anti-immigration, anti-Muslim and anti-EU rhetoric are intertwined in broad populist views, and signify the common ground of mainstream national(istic) politics.

An indicator of the fluidity of (far-)right wing positions is not only the circumstances of the Brexit decision in 2016, and its political aftermath in the UK today, but also the implications of the 2017 parliament election in Austria: the right wing neo-liberal conservative and anti-refugee ÖVP (Austrian people party) and its leader, Sebastian Kurz, considers a coalition with the far-right FPÖ (Freedom Party of Austria) and its leader, Heinz-Christian Strache. Though the right wing parties here are not explicitly anti-EU they agree on (orthodox) Islam as the Other in Europe. Further legal restriction of social welfare rights for refugees from the Middle East, is already in planning.

As argued elsewhere (Vieten 2016: 624):

'An important reference point of claiming that the 'we-I', was 'here' before 'the Otherstranger-them', adds to the established rhetoric of local and national territory ownership, a new dimension of culturalised and Europeanised notions of belonging: a cultural-liberal European cosmopolitanism and a mainstreamed liberal gender discourse encompassing it. This culturist Europeanism adds a new layer to what is regarded as far right populist racism 
and why 'gendered culturalism' has become the populist racist focus in Europe. Thus, the claim of being 'nativist European' goes beyond the local and a nationalistic anchoring, and mystifies Christian cultural heritage, at large. That said, contemporary far right populism subscribes to supra-national aspects of 'European cultural belonging' as a 'liberal' culturalism agenda; paired with a 'crusade' against Islam.'

In hindsight it seems only the strong national welfare state of the late $20^{\text {th }}$ century was able to tame temporarily gendered class and culturalised ethno-religious conflicts in Europe: the transformation of national societies, economies, localities (e.g. austerity; lack of social solidarity) - at least partially - contributes to a lack of social cohesion and accelerates exclusion of underprivileged groups of society. Remarkably, 'communitarian' arguing elites as epitomised by PM Theresa May have been voted into power. Their narrative of a 'break' with previous policy and politics appeal to those who feel betrayed by the political elites, who have been previously in charge. The new 'old' rhetoric is to slam those in favour of cosmopolitan culture or blame international elites.

Supporting Rogers Brubaker's suggestion that 'Civilizationism' (Brubaker, 2017) encompasses situated populist discourses in some EU countries, it is argued here as detailed above that beyond this observation with respect to contemporary racist far-right populism civilizational superiority was yet built in a Germanic discourse of culturalist cosmopolitanism. Though 'culturalist' cosmopolitanism was a historical phenomenon in nineteenth century Germany its ideological shadow impacts contemporary fused (blended horizons) notions of new cosmopolitanism and current populism in Europe.

The central question remains how social disintegration in contemporary nation states might be challenged democratically on the European and international level. With European integration in limbo the continuity of national(ist) territorial democracy, on the one hand, and a global transformation of socio-cultural belonging, identity and solidarity, on the other, clashes and creates populist territorialism.

\section{References}

Ball, J. (2017) Post-Truth - How Bullshit Conquered the World, London: Biteback Publishing.

Bhabha, H.K. (1996) 'Unsatisfied: notes on vernacular cosmopolitanism' in: L. GarciaMoreno and P.C. Pfeiffer (eds.) Text and Nation: Cross-disciplinary Essays on Cultural and National Identities, Columbia: Camden House, 191-207. 
Broeders, D. (2007) The New Digital Borders of Europe: EU Databases and the Surveillance of Irregular Migrants, International Sociology, 22, 1, 71-91.

Brubaker, R. (2017) Between Nationalism and Civilizationalism: The European Populist Moment in Comparative Perspective, Ethnic and Racial Studies, 40, 8, 1191-1226.

Calhoun, C. (2002) Imagining Solidarity: Cosmopolitanism, Constitutional Patriotism and the Public Sphere, Public Culture, 14, 1, 147-171.

Calhoun, C. (2007) Nations Matter: Culture, History and the Cosmopolitan Dream, New York: Routledge.

Calhoun, C. (2017) Populism, Nationalism, Brexit, in W. Outhwaite (ed.), Brexit: Sociological Responses, London: Anthem Press, 57-76.

Cheah, P. (2006) Cosmopolitanism, Theory, Culture \& Society, 23, 486-496.

Cheah, P., and Robbins, B. (eds.) (1998) Cosmopolitics: Thinking and Feeling Beyond the Nation, Minneapolis: University of Minnesota Press.

Clifford, J. (1992) Travelling Cultures, in L. Grossberg, C. Nelson and P.A. Treicher (eds.), Cultural Studies, New York and London: Routledge, 96-112.

Feischmidt, M., and Hervik, P. (2015) Mainstreaming the Extreme: Intersecting Challenges from the Far Right in Europe Intersections. East European Journal of Society and Politics (EJSP), 1, 1, 3-17.

Geschiere, P. (2009) The Perils of Belonging: Autochthony, Citizenship, and Exclusion in Africa and Europe, University of Chicago Press.

Glick Schiller, N. (2010) Old Baggage and Missing Luggage: A Commentary on Beck and Sznaider's Unpacking Cosmopolitanism for a Social Sciences: A Research Agenda, The British Journal of Sociology, 61,1,1 413-420.

Hannerz, U. (1990) Cosmopolitans and Locals in World Culture, Theory, Culture \& Society, 7, 237-251.

Hay, C. (1996) 'Narrating Crisis: The discursive construction of the "winter of discontent"”, Sociology, 30, 2, 253-277.

Hillebrand, E. (ed.) (2014) Right Wing Populism in Europe: How Do We Respond?, Berlin: Friedrich Ebert Stiftung.

Hofmann, H. (2003), "Die Welt ist keine politische Einheit sondern ein politisches Pluriversum“ (54-58) Menschenrecht im Pluriversum?, in: Manemann, Jürgen (2002), Carl Schmitt und die Politische Theologie - Politischer Anti-Monotheismus, Münster: Aschendorff Verlag, 111-123. 
Hogenstijn, M., Van Middelkoop, D., and Terlow, K. (2008) The Established, The Outsiders and Scale Strategies: Studying Local Power Conflicts, The Sociological Review, $56,1,144-161$.

Jansen, R.S. (2015) Populist Mobilization: A New Theoretical Approach, in: C. de la Torre (ed.), The Promise and Perils of Populism: Global Perspectives, Lexington: University Press of Kentucky, 159-88.

Kofman, E. (2005) Figures of the Cosmopolitan: Privileged Nationals and National Outsiders, Innovation, 18, 1, 83-97.

Lash, Ch. (1979) The Culture of Narcissism: American Life in an Age of Diminishing Expectations, New York/London: W.W. Norton \& Company.

Leitner, H. and P. Ehrkamp (2006) 'Transnationalism and migrants' imaginings of citizenship'. Environment and Planning A vol. 38. 1615-1632.

Levinas, E $(1974 ;$ 1991) Otherwise than Being or Beyond Essence, Dordrecht and Boston: Klunner Academic Publisher.

Mawani, R. (2012) Racial Violence and the Cosmopolitan City, Environment and Planning D: Society and Space, 30, 1083-1102.

Mignolo, W.D. (2000) The Many Faces of Cosmo-polis: Border Thinking and Critical Cosmopolitanism,

http://www.duke.edu/ wmignolo/InteractiveCV/Publications/ManyFacesCosmopolis.

Mignolo, W.D. (2002) The Many Faces of Cosmo-polis: Border Thinking and Critical Cosmopolitanism, in: C.A. Breckenbridge, S. Pollock, H.K. Bhabha and D. Chakrabarty (eds.), Cosmopolitanism, Durham and London: Duke University Press, 157-187.

Mouffe, Ch. (1993) 'Pluralism and Modern Democracy: Around Carl Schmitt', in: Chantal Mouffe (1993), The Return of the Political, London; New York: Verso, 117-134.

Mouffe, Ch. (1999) 'Carl Schmitt and the Paradox of Liberal Democracy', in: Chantal Mouffe (ed.), The Challenge of Carl Schmitt, London; New York: Verso, 38- 53.

Mouffe, C. (2004), The Limits of Liberal Pluralism: Towards and Agonistic Multipolar World Order, in A. Sajó (ed.), Militant Democracy, Utrecht: Eleven International Publishing, 69-80.

Mouffe, C. (2005) On the Political, London: Routledge.

Mouffe, C. (2008) Which World Order: Cosmopolitan or Multipolar? Ethical Perspectives, $15,4,453-467$. 
Mudde, C. (2015) Conclusion: Some Further Thoughts on Populism, in C. de la Torre (ed.), The Promise and Perils of Populism - Global Perspectives, Lexington: University Press of Kentucky, 431-451.

Nava, M. (2002) Cosmopolitan Modernity: Everyday Imaginaries and the Register of Difference, Theory, Culture \& Society, 19, 1-2, 81-100.

Nava, M. (2007) Visceral Cosmopolitanism: Gender, Culture and the Normalisation of Difference, London: Bloomsbury Publishing.

Nedelcu, M. (2012) 'Migrant's New Transnational Habitus: Rethinking Migration Through a Cosmopolitan Lens in the Digital Age', Journal of Ethnic and Migration Studies, 38, 9, 1339-1356.

Nwanko, I.K. (2005) Black Cosmopolitanism: Racial Consciousness and Transnational Identity in the Nineteenth-Century Americas, Philadelphia: University of Pennsylvania Press.

Olsen, J. P. (2002) The Many Faces of Europeanization, Journal of Common Market Studies, 40, 5, 921-952.

Painter, A. (2014) Honesty, Statecraft and Engagement: Three Remedies Against Right Wing Populism in Europe, in E. Hillebrand (ed.), Right Wing Populism in Europe: How Do We Respond?, Berlin: Friedrich Ebert Stiftung, 4-6.

Parker, O. (2012) The Ethics of an Ambiguous Cosmopolitics: Citizens and Entrepeneurs in the European Project, International Theory, 4, 2, 198-232.

Pârvu, Camil-Alexandru (2016) Populism, Cosmopolitanism and the Reconfiguration of Contemporary Politics, Analele Universității din București, Seria Stiințe Politice, nr. 1/2016, 103-119 (ISSN 1582-2486) http://anale.fspub.unibuc.ro/

Savage, M. et al. (2005) Globalisation and Belonging. London: Sage.

Schmitt, C. (1950), Der Nomos der Erde im Völkerrecht des Jus Publicum Europaeum, Köln: Greven Verlag.

Taggart, P. (2000) Populism, Buckingham: Open University Press.

Thym, D. (2016) 'Citizens' and 'Foreigners' in EU Law: Migration Law and its Cosmopolitan Outlook, European Law Journal, 22, 3, 296-316.

Vieten, U.M. (2007) Situated Cosmopolitanisms: The Notion of the Other in Discourses on Cosmopolitanism in Britain and Germany, $\mathrm{PhD}$ Thesis submitted to the University of East London, UK (UEL).

Vieten, U. M. (2011) Situating Contemporary Cosmopolitanism in Britain and Germany: Who is the Other, anyway? in: P. O'Donovan and L. Rascaroli (eds.) The Cause of 
Cosmopolitanism - Dispositions, Models, Transformations. Oxford, Bern, Berlin, Bruxelles, Frankfurt am Main, New York, Wien: Peter Lang Publisher, 89-114.

Vieten, U.M. (2012) Gender and Cosmopolitanism in Europe: A Feminist Perspective, Farnham: Ashgate.

Vieten, U.M. (2014) Introduction: Keeping Young's Legacy Alive: Why does Understanding Normalisation Matter to Difference, Democracy and Inclusion?, in U.M. Vieten (ed.), Revisiting Iris Marion Young on Normalisation, Inclusion and Democracy, London: Palgrave Macmillan, 1-16.

Vieten, U.M. (2016) Far Right Populism and Women: The Normalisation of Gendered Anti-Muslim Racism and Gendered Culturalism in the Netherlands, Journal of Intercultural Studies, 37, 6, 621-636.

Walby, S. (2015) Crisis, Cambridge: Polity Press.

Walzer, M. (1980) Radical Principles: Reflections of an Unreconstructed Democrat, New York: Basic Books, Inc., Publishers.

Werbner, P. (1999) Global Pathways: Working Class Cosmopolitans and the Creation of Transnational Ethnic Worlds, Social Anthropology, 7, 1, 17-35.

Werbner, P. (2006) Vernacular Cosmopolitanism, Theory, Culture \& Society, 23, 2-3, 496-498.

Wodak, R. (2013) Critical Discourse Analysis, London: Sage.

Wodak, R. (2015) The Politics of Fear: What Right Wing Populist Discourses mean, London: SAGE.

Wodak, R. (2017) The 'Establishment', 'the Elites', and 'The People': Who is Who?, Journal of Language and Politics, 16, 4, 551-565.

Yuval-Davis, N. (2011) The Politics of Belonging: Intersectional Contestations, London: Sage.

Yuval-Davis, N. (2012) The Double Crisis of Governability and Governmentality, Soundings, 52, 12, 88-99.

Yuval-Davis, N., and Vieten, U.M. (2018 forthcoming) Citizenship, Entitlement and Autochthonic Projects of Belonging in the Age of Brexit, in S. Ellis (ed.), Enfranchising Ireland? Identity, Citizenship and State, Dublin: Royal Irish Academy.

Zùquete, J.P. (2015) 'Free the People': The Search for 'True Democracy' in Western Europe's Far Right Political Culture, in: C. de la Torre (ed.), The Promise and Perils of Populism: Global Perspectives, Lexington: University Press of Kentucky, 231-264. 
${ }^{1}$ My italics, UMV.

${ }^{2}$ Radical left wing populism also contrasts 'the people' with 'the elite'. But here in this chapter I will concentrate on far-right and racist populism. With respect to radical political mobilisation of people against 'auterity' elites far-left ( $\Sigma$ YPIZA / Syriza) and far-right - neo-Nazi populist parties (Golden Dawn) established themselves as political parties in Greece.

$3 \mathrm{https} / /$ www.theguardian.com/politics/2017/oct/13/brexit-vote-creates-surge-in-eu-citizenshipapplications (accessed 5.11.2017).

${ }^{4}$ See also Glick Schiller's (2010) critique of Beck and Sznaider's writings.

${ }^{5}$ The notion of 'multiversum' was re- introduced in the German discourse in the 1920s and by Max Scheler linked to Europäität though it originated in an Anglo-American context. The philosopher William James used the term in his 1909 lecture on A Pluralistic Universe.

${ }^{6}$ In 1993 and 1999 Mouffe published two articles that support Schmitt's arguments about the biased order of 'the political'. Whereas she compared the contributions of Hans Kelsen and Hermann Heller in her earlier article $(1993: 128,129)$ she does not mention these social democrats in her later work of 1999. Both scholars, who were contemporaries of Schmitt, advocated a liberal and positivist Austro-Jewish and German Jewish tradition of legal-political thinking. Heller in particular can be regarded as one of the decisive intellectual figures whose intellectual legacy influenced the German principle of the welfare state (Sozialstaatsprinzip,) of the FRG, which still remains one of the core constitutional principals of social market democracy in Germany.

7 http://www.independent.co.uk/news/uk/politics/theresa-may-speech-tory-conference-2016-in-fulltranscript-a7346171.html (accessed 4.11.2017).

${ }^{8} \mathrm{https}: / /$ www.theguardian.com/politics/blog/live/2016/oct/05/theresa-may-speech-tory-conservativeconference-theresa-mays-speech-politics-live.

${ }^{9}$ The so called 'Paradise Papers' illustrate the scale and in detail how the 'super' rich escape national taxations while using legal possibilities of off-shore business.

https://www.theguardian.com/news/2017/nov/05/what-are-the-paradise-papers-and-what-do-they-tell-us, (accessed 9.11.2017)

${ }^{10}$ NZZ 6.1.2015 'Saturiertheit und Mangel an Empathie' (Saturation and a lack of empathy)

$11 \mathrm{http} / /$ www.europarl.europa.eu/atyourservice/en/20170426PVL00115/Two-years-until-the-2019European-Elections (accessed 5.11.2017).

${ }^{12} \mathrm{http} / / /$ www.europarl.europa.eu/pdf/eurobarometre/2017/2019ee/two_years_until_ee2019_sociodemo_foc us_en.pdf (accessed 5.11.2017).

${ }^{13}$ http://www.lisbon-treaty.org/wcm/the-lisbon-treaty/treaty-on-European-union-and-comments/title-6final-provisions/137-article-50.html. (accessed 10.11.2017).

${ }^{14} \mathrm{http}: / /$ eur-lex.europa.eu/LexUriServ/LexUriServ.do?uri=CELEX:12008E045:EN:HTML, (accessed 10.11.2017).

$15 \mathrm{http} / / /$ ec.europa.eu/eurostat/statistics-explained/index.php/Migration_and_migrant_population_statistics (accessed 5.11.2017).

${ }^{16} \mathrm{https}: / /$ ec.europa.eu/programmes/erasmus-plus/individuals_en (accessed 5.11.2017).

${ }^{17}$ See for example, http://network-eventberlin.de/ (accessed $\left.\overline{5} .11 .2017\right)$.

${ }^{18}$ See for some of these aspects news coverage on the New Year's Eve sexual assaults on women in Cologne and Hamburg, Germany, http://www.theguardian.com/world/2016/jan/05/germany-crisis-cologne-newyears-eve-sex-attacks; http://www.newstatesman.com/world/europe/2016/01/how-deal-new-years-evesexual-assaults-cologne-and-hamburg (accessed 5.11.2017). 